\title{
Eucalyptus Plantation in Farmlands: A Prospective Source of Economic Returns in Bhabar Terai Zones of Nepal
}

\author{
Shiva S. Neupane ${ }^{1}$
}

\begin{abstract}
The Bhabar Terai zone lies immediately at the foot of the Siwalik hills and consist of bouldery and gravelly areas derived from alluvial fans at the base of the hills. Many of the streams flowing from the hills disappear into the very freely drained soil of this area to reappear again in the Terai proper. The soil is not good for the production of food/cereal crops. Eucalyptus species is fast growing and can grow on wide range of climatic conditions. There are special types of farm relations with Eucalyptus in Bhabar Terai. Most of the farmers in this region have Eucalyptus plantations to support their livelihood. It is obvious that Eucalyptus is one of the appropriate tree species to grow in Siwalik and Bhabar zones to get more economic return within the short period of time. Farmers have been accepting to grow Eucalyptus as an integral part of their overall farming systems to maximize their annual income from the same piece of land along with the other tree and cereal crops combinations from the sale of these tree products.

शिवालिक पहाडको फेदीमा अवस्थित भावर तराई क्षेत्र दोमट, गेगरीन, ग्राभेल र वलौटे माटोवाट बनेको छ। शिवालिकवाट बग्ने अधिकांश खहरे खोलाहरु भावरमा आउँदा पानी विहिन हुन्छन, त्यही खोलामा तराईको तल्लो भू-भागमा पर्याप्त पानी बगेको देखिन्छ। यस क्षेत्रको माटो अन्न वाली उत्पादनको लागि त्यति उपयुक्त छैन। मसला एउटा छिटो बढ़ने र विभिन्न हावापानीमा हुर्कन सक्ने प्रजाती भएकोले भावर क्षेत्रमा खेती प्रणाली र मसला वृक्षारोपणको विशेष सम्बन्ध रहेको देखिन्छ। यस क्षेत्रका अधिकांश कृषकहरुले आफ्नो जिवीकोपार्जनमा टेवा पुच्याउन मसलाको वृक्षारोपण गरिरहेका छन्। यो कुरा प्रष्ट छ कि, शिवालिक र भावर क्षेत्रमा वृक्षारोपण गरी छोटो समयमा आम्दानी लिनको लागि मसला नै उपयुक्त प्रजाती हो। कृषकहरुले आफुसँग भएको सिमित जग्गामा वन प्रजाती र अन्न वालिको मिश्रित खेती गरी विभिन्न उपजहरुको बिक्रिवाट वार्षिक आम्दानी वृद्धि गर्न मसला वृक्षारोपणलाई समग्र खेती प्रणालीको एउटा अभिन्न अंगको रुपमा स्वीकारेका छन्।
\end{abstract}

Key Words: Bhabar Terai, Eucalyptus plantation, Economic returns, Livelihood support

\section{Introduction}

The Terai cover approximately 35,000 square kilometers out of Nepal's 147,181 square kilometers, which is analogous to $24 \%$ (Larsen 2000). The Bhabar Terai lying at $150 \mathrm{~m}$ above sea level is gravel sand out wash zone of the Siwalik range of the Himalayan chain. Here a sharp monsoon sub tropical climate interacts with freely drained soils and deep water tables to present soil moisture deficits and major adverse problems in food crops and tree growths. The Bhabar Terai zone lies immediately at the foot of the Siwalik hills, and consists of bouldery and gravelly areas derived from alluvial fans at the base of the hills.

\footnotetext{
${ }^{1}$ Terai Private Forest Development Association (TPFDA), Dhanusha, Nepal, Email: ssneupane@gmail.com
} 
Many of the streams flowing from the hills disappear into the freely drained soil of this area to reappear again in the Terai proper. Surface water supply is scanty, and digging wells is difficult because of the bouldery subsoil (Jackson, 1994). The land is not very good for food and other cereal crops production.

The rivers flowing through Terai have broad, very flat, bouldery beds, through which, in the dry season often only a trickle of water flows. The banks are ill-defined,

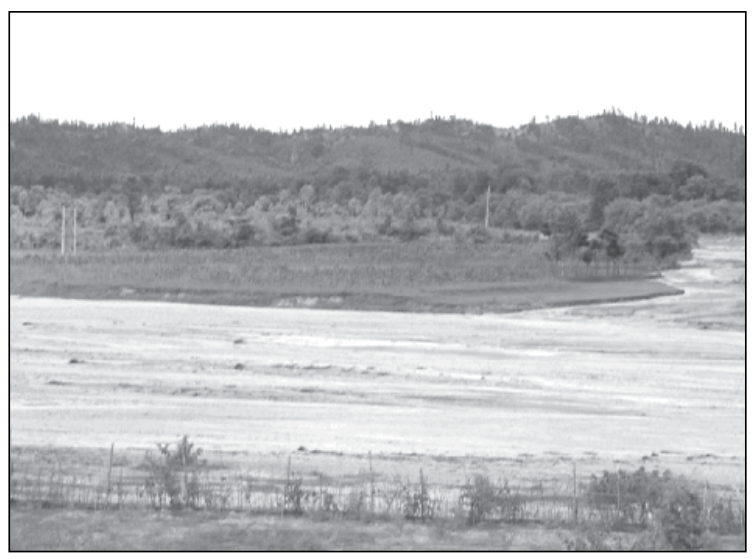

Photo 1: Foots of the Siwalik hills/Bhabar area and especially in the Bhabar Terai zone, the rivers tend to erode laterally rather than to deepen their beds. They tend to change course frequently, often with disastrous consequences.

It is obvious that there is a low production potentiality of different food cereal crops in this area. Farmers have to explore alternative sources of production to sustain their day to day lives as they have inhabited in this zone. Farming system, on the other hand, is absolutely at subsistence level. The rural population in Bhabar, basically, is dependent on wooden products for cooking and supplement for livestock fodder. About $75 \%$ of the total energy consumption in Terai comes from forest products i.e. fuel wood (White, 1986).

\section{Methodology}

This article is developed based on the desk study and/or the review of the existing literatures related to Eucalyptus plantations and product marketing by local farmers who produce the tree and associated products in the local area rather than the direct study in the field. However, some observations in the field have been made for practical verifications.

\section{Eucalyptus and subsequent farming systems}

When we talk about Eucalyptus, most of them are native to Australia but some of them may be from Papua New Guinea, Philippines and Indonesia. Almost all Eucalyptus are evergreen (White, 1988c; Jackson, 1994). Eucalyptus tolerates infertile acidic sandy or rocky soils, or water-logging. It demonstrates moderate salt tolerance. Increasing salinity is

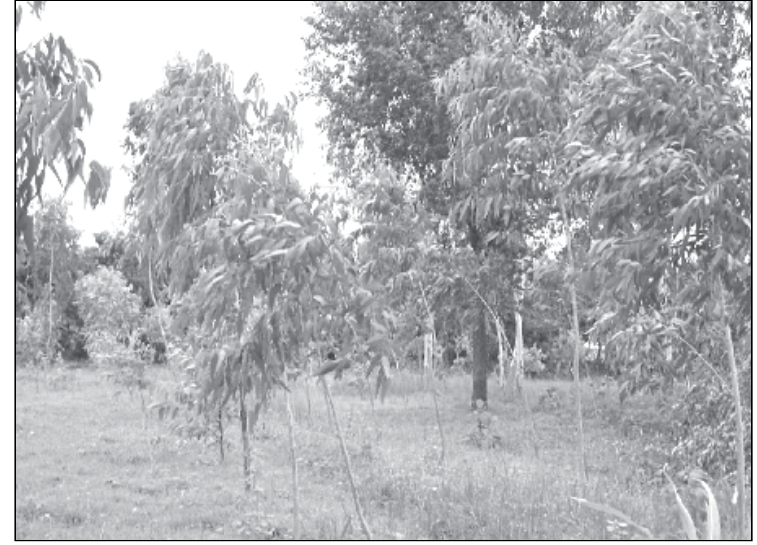

Photo 2: Eucalyptus plantation in individual farm land 
associated with reduced tree growth. Growth is better for $E$. camaldulensis trees planted on non-saline soil than on moderately saline soil. An increase in soil salinity is associated with a decrease in the average leaf area per tree. It can grow on wide range of climatic conditions. Normally, this plant is drought tolerant and is suitable to grow under arid and semi arid conditions. There is special type of farm relation with Eucalyptus species basically in Bhabar Terai. Most of us know that this plant is one of the fast growing tree species. It grows tall, straight with clean bole. The tree has high crown and prominent tap root system. The outstanding feature of this plant is that it is not browsed by cattle. Besides, it is good for small timbers and utility/transmission poles, fuel wood and charcoal production. The calorific value of dry fuel wood is $4880 \mathrm{Kcal}$ per $\mathrm{kg}$ (Singh, 1995).

The farmers on the other hand, after the failure of Sisoo (Dalbergia Sisoo) plantation in Terai in the past, have chosen Eucalyptus as an alternative tree species and have been planting with other food crops in their farm lands in the form of adopted agro forestry practices which they learnt from Sagarnath pilot plantations. Our experiences from Terai Private Forest Development Association (TPFDA) in Dhanusha district also suggest that farmers have difficulty to sustain their farming systems in the Bhabar areas due to unproductive lands which is directly linked with their livelihoods. As Eucalyptus is one of the fast growing spp. and can grow in wide range of soil types, it is obvious that Eucalyptus is the appropriate tree species to grow in Siwalik and Bhabar zones to get more economic returns within the short period of time (Jacobs, 1979). Farmers have been accepting it to grow as an integral part of their overall farming systems to maximize their annual incomes from the same piece of land along with the other tree and cereal crops combinations.

Table 1: Eucalyptus growth performances

\begin{tabular}{|c|c|c|}
\hline S.N. & Age (yrs) & Average Diameter $(\mathbf{c m})$ \\
\hline 1 & 2 & 3.84 \\
\hline 2 & 3 & 8.61 \\
\hline 3 & 4 & 9.35 \\
\hline 4 & 5 & 10.35 \\
\hline 5 & 6 & 14.30 \\
\hline
\end{tabular}

Source: Growth measurement report by TPFDA, 2007

Farmers can grow about 37 trees of Eucalyptus per katha of land $(1$ Hectare = 1.5 Bigaha $=30$ Kattha) with $3 \mathrm{~m} \times 3 \mathrm{~m}$ spacing along with the other crops combinations recognized as intensive agroforestry models. Table 1 shows that a two years old Eucalyptus tree can have $3.84 \mathrm{~cm} \mathrm{DBH}$ and similarly $8.61 \mathrm{~cm}$ for three years, $9.35 \mathrm{~cm}$ for four years, 10.35 $\mathrm{cm}$ for five years and $14.30 \mathrm{~cm}$ for six years respectively (Growth Measurement Report/ 
TPFDA, 2007). A 5-6 years old Eucalyptus tree as shown in table 1 can give one electricity pole/transmission pole, Koro for thatch house making and fuel woods for cooking and heating purposes.

During $5^{\text {th }}$ years of plantation in normal soil condition with intensive care by farmers, about $25 \%$ of total survived trees will reach harvestable size for utility/ electricity pole. If the farmers have Eucalyptus tree stand then they can have economic returns (Market Study Report/

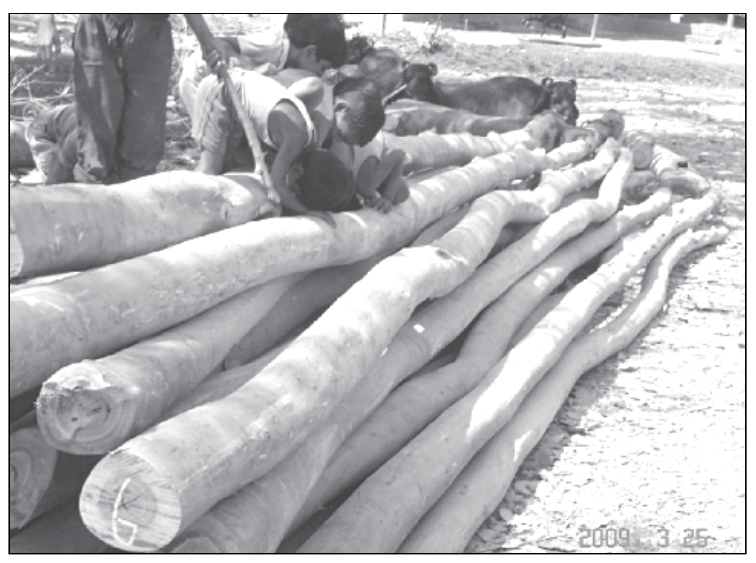

Photo 3: Electricity poles TPFDA, 2009) as given in the following table 2 in their own local markets.

Table 2: Products sale and subsequent incomes

\begin{tabular}{|c|l|c|c|}
\hline S.N. & \multicolumn{1}{|c|}{ Products } & Unit & Local market price(Rs.) \\
\hline 1 & Electricity/transmission pole & Per piece & 1000.00 \\
\hline 2. & Seed & Per Kg & 800.00 \\
\hline 3. & Koro (small balo/danda) & Per piece & $50.00-100.00$ \\
\hline 4. & Fuel wood & Per quintal & $150.00-200$ \\
\hline
\end{tabular}

Source: Local market study report by TPFDA, 2009

\section{Conclusion}

In Nepal, there is subsistence farming system. The soil in Bhabar area is not very good for the production of food/cereal crops. The rural population in Bhabar basically is dependent on wooden products for cooking and supplement for livestock fodder. Eucalyptus plant is one of the fast growing tree species. It grows tall, straight with clean bole. The tree has high crown and prominent tap root system. The outstanding feature of this plant is that it is not browsed by cattle. Beside, it is good for small timbers and very good for utility/transmission poles, fuel wood and charcoal production. Farmers can have more benefits from Eucalyptus tree plantations in the Bhabar area than from the other food crops. It would be better if the farmers are encouraged for plantation of Eucalyptus with other tree crops combinations as an agroforestry model rather than that of Eucalyptus mono-crops/single crops to improve their land productivity. Hence, Eucalyptus plantation in farmlands can really be a prospective source of economic returns to support their livelihoods in Bhabar zones. 


\section{Reference}

Demo Plot Report 2007. Eucalyptus Growth Measurement Report. Terai Private Forest Development Association (TPFDA), Dhanusha, Nepal.

Jackson, J. K. 1994. Manual of Afforestation in Nepal. Vol (2).

Larsen C. 2000. Wood Trading in Connection to the Project Forestry Extension Services in Central Terai, Nepal.

Marketing Reports 2009. Report on Assessment of Existing Local Markets of different Agroforestry Products. Terai Private Forest Development Association (TPFDA), Dhanusha, Nepal.

Singh, S. P. 1995. Favorite Agroforestry Trees. Udaipur 313001. Agrotech Publishing Academy

White, K. J. 1986.Tree Farming Practices in the Bhabar Terai of Central Nepal. Manual-2.Plantation Consultant, Sagarnath Forest Development Project, Ministry of Forest Kathmandu. 